\title{
Aldehyde dehydrogenase as a marker and functional mediator of metastasis in solid tumors
}

\author{
Mauricio Rodriguez-Torres ${ }^{1,2}$ • Alison L. Allan ${ }^{1,2,3,4,5}$
}

Received: 21 June 2015/Accepted: 1 October 2015/Published online: 7 October 2015

(C) The Author(s) 2015. This article is published with open access at Springerlink.com

\begin{abstract}
There is accumulating evidence indicating that aldehyde dehydrogenase (ALDH) activity selects for cancer cells with increased aggressiveness, capacity for sustained proliferation, and plasticity in primary tumors. However, emerging data also suggests an important mechanistic role for the ALDH family of isoenzymes in the metastatic activity of tumor cells. Recent studies indicate that ALDH correlates with either increased or decreased metastatic capacity in a cellular context-dependent manner. Importantly, it appears that different ALDH isoforms support increased metastatic capacity in different tumor types. This review assesses the potential of ALDH as biological marker and mechanistic mediator of metastasis in solid tumors. In many malignancies, most notably in breast cancer, ALDH activity and expression appears to be a promising marker and potential therapeutic target for treating metastasis in the clinical setting.
\end{abstract}

Keywords Aldehyde dehydrogenase $\cdot$ Metastasis $\cdot$ Solid tumors $\cdot$ Cancer stem cell $\cdot$ Biomarker

Alison L. Allan

alison.allan@lhsc.on.ca

1 London Regional Cancer Program, London Health Sciences Centre, London, ON, Canada

2 Department of Anatomy \& Cell Biology, Schulich School of Medicine and Dentistry, Western University, London, ON, Canada

3 Department of Oncology, Schulich School of Medicine and Dentistry, Western University, London, ON, Canada

4 Lawson Health Research Institute, London, ON, Canada

5 London Regional Cancer Program, Room A4-132, 790 Commissioners Road East, London, ON N6A 4L6, Canada

\section{Introduction}

Metastasis is a life-threatening systemic condition, with ninety percent of all cancer deaths resulting from cancer cell dissemination from the primary tumor to distant vital organs [1]. Navigation of the metastatic cascade is a complex, multistep process involving multiple tumor cell phenotypes, body compartments, and accelerated evolutionary cell trajectories [2]. Accordingly, in spite of enormous and earnest progress in elucidating the mechanisms that drive metastasis, the mortality of metastatic cancer has improved very little in the last several decades [3].

Despite the deadly nature of metastasis, it is a remarkably inefficient process. In fact, only a small fraction of cancer cells that survive in the systemic circulation are able to give rise to clinically relevant metastases [4]. Therefore, the identification, isolation, and characterization of potential metastasis-initiating cell (MIC) subpopulations has become a priority for many metastasis research groups including ours. One of the most attractive candidates for MICs are putative cancer stem cells (CSCs), which have been identified in a diverse array of hematopoietic and solid tumor types (reviewed in [5] and [6]). These CSC subpopulations can be defined by their capacity for sustained self-renewal and the ability to give rise to the heterogeneous population of cancer cells that make up a tumor. Importantly, it has also been shown that cells with a CSC phenotype characterized by high aldehyde dehydrogenase (ALDH) activity have an enhanced capacity for metastatic behavior in vitro (adhesion, colony formation, migration, and invasion) and/or metastasis in vivo [7-11], supporting the hypothesis that CSCs might act as the MIC subpopulation.

In the past several decades, increasing evidence has supported the role of ALDH as a biological marker for 
stem-like cancer cells and aggressive tumor cell behavior, as well as an indicator of poor clinical outcome with particular prominence in breast cancer experimental models and clinical studies (reviewed in [5, 12-15] ). In addition to its role as a detoxifying enzyme and key mediator of stem/ progenitor cell expansion and differentiation, the functional and mechanistic involvement of ALDH in tumor initiation and progression has become a topic of considerable interest in the cancer field. While the involvement of ALDH in primary tumor formation, therapy resistance, and malignant behavior in vitro has been extensively described in the literature (reviewed in $[5,12-14,16]$ ), the role of ALDH in metastasis has been less evident. The purpose of this review is to highlight the most recent evidence supporting a specific role for ALDH in metastasis, both in pre-clinical mechanistic studies and in vivo models, as well as in the clinical setting. Clarification of the tumor types affected, the isoforms implicated, and the underlying molecular mechanisms of ALDH in driving metastasis is necessary in order to achieve effective translational targeting of this important enzyme.

\section{The human ALDH superfamily}

Nineteen different ALDH functional genes and multiple splice variants have been characterized to date. Although they are widely expressed in multiple different tissues, these ALDH isoforms display tissue- and organ-specific expression patterns and have also been found in various cellular subcompartments including the cytosol, nucleus, mitochondria, and endoplasmic reticulum (reviewed in [5] ). In these locations, ALDH catalyzes the oxidation of aldehydes to their corresponding carboxylic acids. For example, different ALDH families are capable of detoxifying highly reactive aldehydes that are products of lipid peroxidation (ALDH1, ALDH3, ALDH8) [17-19]. Others are critical regulators of the retinoic acid pathway through involvement in the catalysis of retinaldehyde to retinoic acid, and therefore play an important role in stem and progenitor cell expansion and differentiation (ALDH1A1, ALDH1A2, ALDH1A3) [20]. ALDH also has been found capable of inactivating xenobiotics, including the alkylating agent cyclophosphamide (CP) and analogous chemotherapeutic drugs (ALDH1A1, ALDH3A1) [21]. In addition, it has been observed that ALDH is mechanistically involved in other diverse cell activities including structural and osmoregulatory functions (ALDH1A1, ALDH3A1, ALDH7A1) [14, 22]. Importantly, the ability of ALDH to regulate cell proliferation and selfprotection is believed to contribute its involvement in mediating CSC capabilities such tumor progression, phenotypical heterogeneity, and therapy resistance [5].

\section{Functional role of ALDH in cancer}

\section{ALDH and retinoic acid signaling in cancer cells}

The retinoic acid signaling pathway has been implicated in normal and cancer cell function including the regulation of gene expression and development [23-26]. In tumor biology, the retinoic acid pathway appears to play a dualistic role involving epigenetic context-dependent differential gene expression, mediation of apoptotic pathways, and immune system regulation $[10,20]$. The human cytosolic ALDH1A subfamily (made up of ALDH1A1, ALDH1A2, and ALDH1A3) irreversibly oxidizes retinaldehyde to retinoic acid (RA). Subsequently, RA is translocated to the nucleus where it is able to regulate the transcriptional activity of more than 500 genes through activation of retinoic acid receptor (RAR), retinoic X receptor (RXR), and nuclear hormone receptors peroxisome proliferator activated receptor beta/delta $(\mathrm{PPAR} / \beta / \delta)$. RA exerts differential effects on tumor growth in a cell context-dependent manner. It has been found that retinoic acid activation of RARs and RXRs is followed by cell cycle arrest and differentiation due to increased transcription of tumor suppressor factors, whereas RA activation of PPARs has been found to mediate the increased expression of oncogenes and subsequent cell cycle progression observed in other experimental model systems (reviewed in [20]). In addition, it has been observed that the influence of RA on tumor growth might be mediated by epigenetic silencing of RA-inducible tumor suppressors [10, 27].

Importantly, RA-producing ALDH isoforms, including ALDH1A1 and ALDH1A3 (but not ALDH1A2), are among the most common ALDH isoforms associated with a diverse arrange of hematopoietic and solid tumors. There is accumulating evidence that their increased expression selects for tumor cell subpopulations exhibiting stem-like or aggressive tumor cell phenotypes, indicating that the tumorigenic "branch" of the retinoic acid pathway might be co-opted in some tumors and/or that other non RAdependent functional roles of ALDH1A1 and ALDH1A3 might be involved in tumorigenesis [7, 9, 10, 28]. For example, ALDH1A1 and ALDH1A3 have been shown to play functional roles in lung and breast cancer cell migration and invasion, although the mechanisms underlying this behavior have not been established [10, 29, 30]. It is of note that RA has been used to dramatically improve clinical outcome in patients with acute promyelocytic leukemia (APL); where ninety-eight percent of patients with this disease carry a fusion of the PML and RAR $\alpha$ genes that impairs the ability of RAR $\alpha$ to induce hematopoietic stem/progenitor cell differentiation at physiological levels of RA [31, 32]. However, attempts to 
use RA to induce tumor cell differentiation in other cancer types have shown mixed results at best in clinical trials (reviewed in [20] and [16]). The potential causes of the disparate results obtained after targeting the retinoic acid pathway in cancer are discussed later in this review.

\section{ALDH plays a self-protective role in cancer cells}

There is increasing evidence implicating ALDH in cancer cell self-protection against both endogenous and exogenous threats. Antioxidant and substrate-specific drug inactivation are among the key mechanisms underlying these capabilities. For example, ALDH has a NADPH recycling function that is believed to support antioxidant cell capabilities. In addition, it has been observed that ALDH is often co-expressed with antioxidant factors and drug efflux channels in cells with high ALDH activity [22, 33-39]. ALDH1A1 and ALDH1A3 are capable of enzymatic inactivation of alkylating agents such as $\mathrm{CP}$ and other oxazaphosphorines [40-43]. Moreover, ALDH appears to confer resistance to drugs other than $\mathrm{CP}$ and analogues including doxorubicin, cisplatin, arbinofuranosyl citidine (Ara-C), temozolemide and taxanes [28, 44-47], although the mechanisms underlying this are less clear. A comprehensive review of ALDH involvement in chemotherapy and radiotherapy resistance has recently been published by Januchowski et al. [21]. Thus, ALDH is not only involved in physiologic and cancer cell proliferation and differentiation, but also in promoting tumor cell survival through direct inactivation, indirect expulsion of xenobiotics, and enhancement of the oxidative stress resistance response.

\section{ALDH as a marker for cancer stem cells}

\section{Assessment of ALDH in cancer research}

Different approaches have been used to quantify ALDH in cancer cells and tumor tissue. Early methods for determining ALDH levels relied on measuring enzyme kinetics or immunoblotting of enzymes released after cell lysis, in addition to immunohistochemical detection. However, these methods are flawed by antibody cross-reactivity between enzyme isoforms and enzyme structural instability [48, 49]. An alternative and more recent approach consists of measuring ALDH activity in viable cells by quantifying the ALDH-mediated intracellular retention of the fluorescent compound BODIPY-aminoacetate $\left(\mathrm{BAA}^{-}\right)$using flow cytometry-based methods [7, 23, 50-52]. This functional assay is commercialized as the ALDEFLUOR ${ }^{\mathrm{TM}}$ assay and depends on the conversion of the uncharged ALDH substrate BODIPY amino acetaldehyde (BAAA), which freely diffuses in and out of the cell, into the negatively charged
BAA-compound. As a result, after addition of BAAA, cancer cell subpopulations with elevated activity of ALDH $\left(\mathrm{ALDH}^{\mathrm{hi}}\right)$ become highly fluorescent and can be identified using flow cytometry gating criteria. The $\mathrm{ALDH}^{\mathrm{hi}}$ cell subset can be distinguished when compared to cells treated with the ALDH1 inhibitor 4-(diethylamino) benzaldehyde (DEAB), which is used as a reference control. Although the ALDEFLUOR $^{\mathrm{TM}}$ assay works well in various human models, there is controversy about its adequacy for identifying cancer stem cells in murine models given disparate results among groups isolating murine HSCs using this technique [53-56]. However, enrichment of murine CSCs have been recently reported using the ALDEFLUOR ${ }^{\mathrm{TM}}$ assay in two different models of mouse breast cancer [57, 58]. In addition, attempts at in vivo stem cell labeling have employed ALDH radiolabeled substrates. However, the resultant charged compounds were not polar enough to be retained into the cells [59].

\section{ALDH isoforms involved in the ALDEFLUOR ${ }^{\mathrm{TM}}$ assay}

Early reports identified ALDH1 as the main ALDH enzyme family responsible for the enzymatic activity reported using the ALDEFLUOR ${ }^{\mathrm{TM}}$ assay $[52,60]$. However, recent controversy has emerged regarding the family and subfamily isoforms acting on the BAAA substrate and thus responsible for the readout in this assay. This distinction is of importance given the ample and tissue-specific distribution of ALDH isoforms in normal tissue, the reliance on the ALDEFLUOR ${ }^{\mathrm{TM}}$ assay for isolation of viable CSCs for subsequent downstream assessment, and differential roles of different ALDH1 isoforms in tumorigenesis and metastasis [10]. In breast cancer, mixed results have been reported regarding the specific ALDH1A isoenzyme involved in tumorigenesis and the ALDEFLUOR ${ }^{\mathrm{TM}}$ assay, with some groups reporting ALDH1A1 as the main enzyme involved and others showing that ALDH1A3 is the accountable isoform $[9,10,61,62]$. Recent research by our group using human breast cancer cell lines indicate that although both isoforms are involved in different phases of the metastatic cascade, $50 \%$ of the ALDEFLUOR ${ }^{\mathrm{TM}}$ activity is driven by the ALDH1A3 isoform with no significant participation of ALDH1A1 in this assay (our unpublished data). In addition, other studies have found enzymatic participation of ALDH1A1, 1A2, 1A3, 2, 7A1 and 8 in the ALDEFLUOR ${ }^{\mathrm{TM}}$ assay in other tumor types [22, 63-65]. Thus, multiple ALDH isoforms may contribute to both the readout of the ALDEFLUOR ${ }^{\mathrm{TM}}$ assay and to cellular function in tumorigenesis in a tissue-specific manner.

It is important to clarify that, by current nomenclature, the term ALDH1 does not accurately describe any of the 
isoforms of the ALDH superfamily [12] and could refer to ALDH1A1, ALDH1A2, ALDH1A3, ALDH1B, ALDH $1 \mathrm{~L} 1$, or ALDH1L2. This is a major problem in the ALDH/cancer stem cell literature, where ALDH1A1 is often used interchangeably with ALDH1 or ALDH. Further confusion arises when ALDEFLUOR ${ }^{\mathrm{TM}}$ positivity is referred to as ALDH1 activity or positivity. To address this ambiguity, in the current review we will refer to ALDEFLUOR $^{\mathrm{TM}}$ positive cells or ALDEFLUOR ${ }^{\mathrm{TM}}$ activity whenever the source refers to a phenotype identified using the ALDEFLOUOR ${ }^{\mathrm{TM}}$ assay. Notably, Pors et al. [12] recently reported that the specific isoform identified using BD Biosciences clone 44 or Abcam ab52492 antibodies against ALDH1 is ALDH1A1. In this review, we will therefore clarify this whenever ALDH1 expression is reported by authors using either of these antibodies. In addition, if the isoform specificity of the ALDH1 antibody could not be established, this will also be noted.

\section{Recent evidence supporting ALDH as a CSC marker}

Multiple markers have been used for enriching cells with stem-like properties from human tumor primary tissue and human cancer cell lines, and this is reviewed exhaustively elsewhere in the literature [6, 66-70]. We have previously reviewed the relevance of ALDH as a marker for normal and cancer stem cells [5]. Thus, for this review we have summarized the latest findings regarding the importance of ALDH as a cancer stem cell marker since 2010 (summarized in Table 1).

\section{ALDH and metastasis}

While there is growing evidence supporting the use of ALDH as a CSC marker and implicating it as having an important functional role in tumor cell self-protection, differentiation, expansion, and therapy resistance, less is known about its functional role in mediating metastasis. In this section we will review the mechanistic involvement of ALDH in metastasis based on experimental evidence derived from assessment of in vitro of cellular behaviors contributing to metastasis, in vivo animal models of metastasis, and patient-derived metastasis samples.

\section{Functional association of ALDH with in vitro cell behaviors related to metastasis}

Different in vitro assays have been used to model and estimate potential metastatic activity in vivo [71]. Clonogenic assays involving loss of substrate adherence or serum-free media, including colony formation in soft agar and tumorsphere growth in ultra-low attachment plates, are correlated with tumorigenicity and stemness. Therefore, they are often used to evaluate the capability of cancer cells to initiate metastatic growth in vivo [72-75]. Assessments of migration and invasion in vitro have also been used to estimate metastatic potential in vivo [71, 72]. In addition, given the intrinsic resistance of metastases to chemotherapy and radiotherapy, in vitro assessment of therapy response has also proven to be useful [72, 74, 76, 77]. ALDH and several of its isoforms have been recently evaluated for and positively correlated with multiple in vitro cell behaviors that are surrogates of metastatic behavior in vivo.

Tumor cells displaying high ALDEFLUOR ${ }^{\mathrm{TM}}$ activity have been demonstrated to have enhanced motility and ability to invade through a 3D basement membrane in breast cancer [7, 78], ovarian cancer [79, 80], osteosarcoma $[36,81]$, esophageal cancer [82], and prostate cancer [11, 83]; as well as increased therapy resistance in breast cancer [28, 84], ovarian cancer [79], osteosarcoma [85], and prostate cancer [86]. ALDEFLUOR ${ }^{\mathrm{TM}}$-positive cells have also been reported to exhibit increased capacity to form tumorspheres in breast cancer [8, 15, 52, 87], human malignant fibrous histiocytoma (HMFH) [88], ovarian cancer [80, 89, 90], brain tumors [91, 92], prostate cancer [11], head and neck squamous cell carcinoma (HNSCC) [93], colon cancer [94, 95], non-squamous cell lung cancer (NSCLC) [96-98], esophageal cancer [82], and cervical cancer [99]. Interestingly, ALDH-positive cells display additional stem-like behaviors such as resistance to hypoxia in ovarian cancer [79] and the capacity for asymmetric division in brain tumor cells [91].

Several specific ALDH isoforms have been correlated with in vitro metastatic behavior. For example, ALDH1A1 expression has been reported to correlate with increased in vitro clonogenic activity in NSCLC [29, 100, 101], esophageal cancer [102], ovarian cancer [90], pancreatic cancer [103], and renal cancer [104]. This ALDH isoenzyme has also been correlated with increased migratory capabilities in lung cancer [29], renal cancer [104], and esophageal cancer [29] and in vitro therapy resistance in lung cancer [105], melanoma [65, 106], and renal cancer [104]. Other ALDH isoforms have been mechanistically associated with metastatic behavior in vitro, including ALDH1A3 in breast cancer [9, 10], melanoma [65], pancreatic cancer [107] and brain cancer [108]; ALDH3A1 in prostate cancer [109] and liver cancer [110]; and ALDH7A1 in prostate cancer [11]. In summary, increasing evidence from in vitro studies suggests a mechanistic role for ALDH in metastasis and have laid the groundwork to further the study of the involvement of this enzyme in metastatic activity in vivo. 


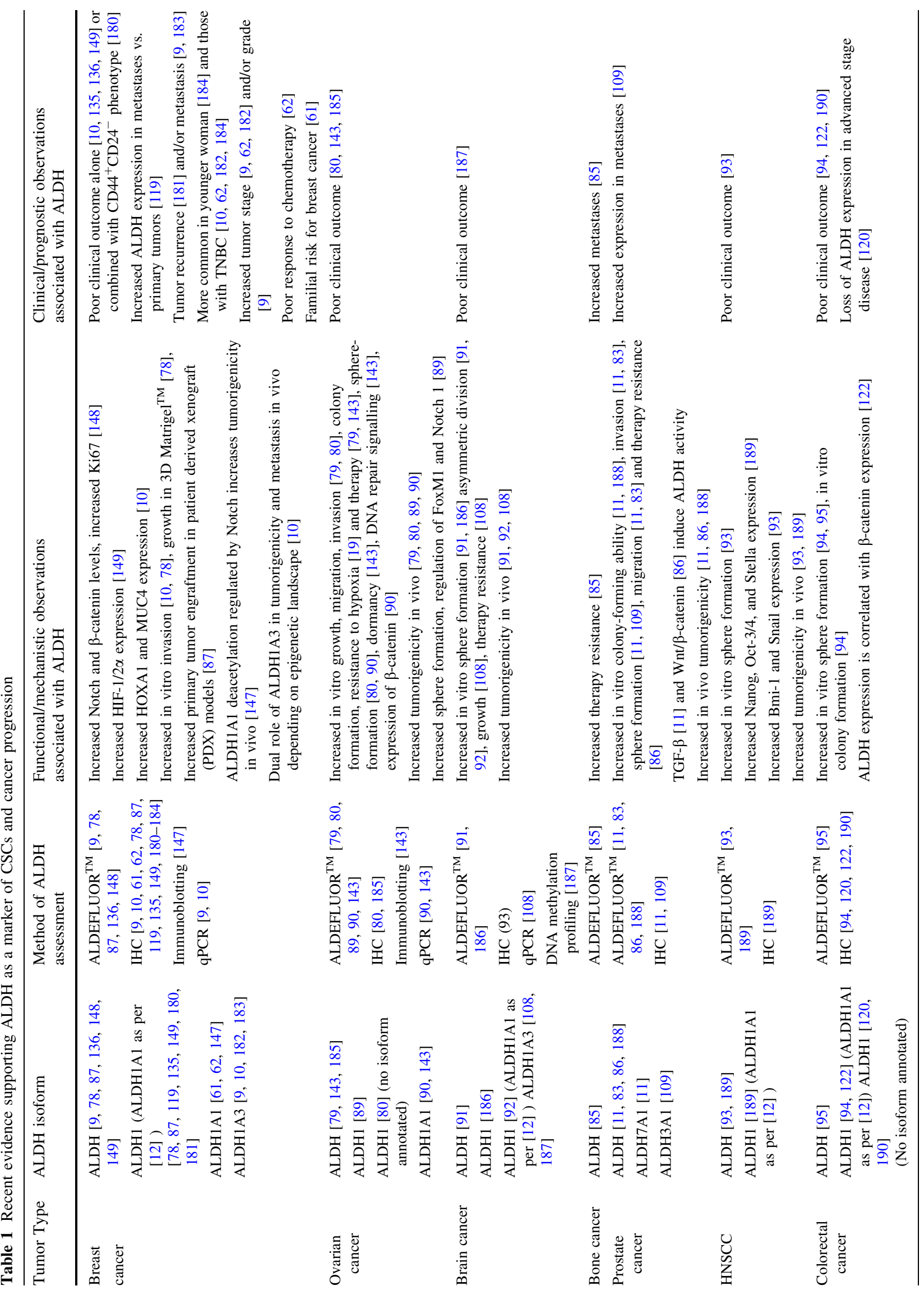




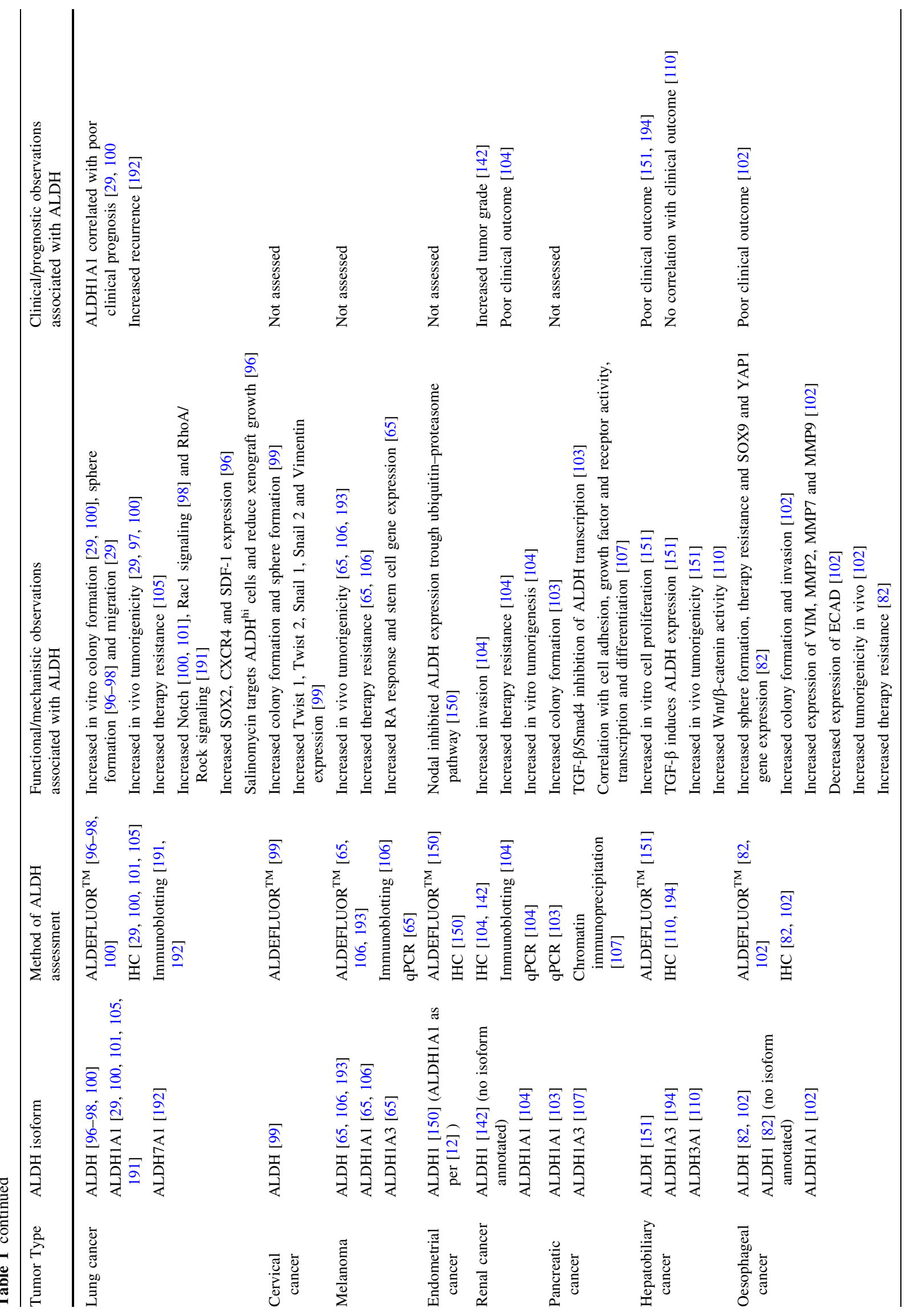




\section{Functional association of ALDH with in vivo metastasis}

Croker et al. [7] and Charafe-Jauffret et al. [111], using the $\mathrm{ALDH}^{\mathrm{hi}} \mathrm{CD} 44^{+} \mathrm{CD} 24^{-}$and $\mathrm{ALDH}^{\mathrm{hi}}$ and phenotypes respectively, provided the first direct experimental evidence implicating ALDH ${ }^{\mathrm{hi}}$ cells in breast cancer metastasis in vivo. Moreover, it was shown that $\mathrm{ALDH}{ }^{\mathrm{hi}} \mathrm{CD} 44^{+} \mathrm{CD} 24^{-}$cells were the only cancer cell subpopulation capable of metastasizing beyond the lungs in a pattern that mirrors the clinical behavior of breast cancer [7]. Concurrently, it was also reported that $\mathrm{ALDH} 1 \mathrm{~A} 1{ }^{+} \mathrm{CD} 44^{+} \mathrm{CD} 24^{+}$cells correlated with metastatic activity in matched primary and metastatic samples from pancreatic cancer [112]. Subsequent studies have shown that high ALDEFLUOR ${ }^{\mathrm{TM}}$ activity enriches for cells with increased metastatic capability in vivo in prostate cancer [83, 113, 114], breast cancer [15, 33], HNSCC [93], osteosarcoma [81], esophageal cancer [102], ovarian cancer [79], hepatic cancer [95], and adenoid cystic carcinoma [115]. More recently, other studies have further investigated the specific ALDH isoenzymes correlated with metastatic activity in vivo. For example, ALDH7A1 has been implicated in prostate cancer metastatic activity after left ventricular injection (LVI) of a prostate cancer cell line [11], while ALDH3A1 has been shown to be associated with metastasis using a mouse tail vein injection model [109]. ALDH1A3 has been observed to be involved in metastasis in vivo in breast cancer after cancer cell xenotransplantation into mouse models [10]. It has also been reported that inhibition of ALDH1A1 by RNA interference in melanoma cell results in reduced metastatic ability in vivo [106], providing functional validation and indicating that ALDH is not only a biological marker for enhanced metastatic ability, but also plays a functional role in metastasis in vivo. Interestingly, in one study, ALDH1A3 was found to promote or inhibit breast cancer metastasis depending on the specific epigenetic context framing retinoic acid signaling in vivo [10]. Another elegant study reported that immune targeting of breast CSCs cancer stem cells using ALDH1A1-specific CD8+ T cells resulted in reduced metastatic activity of breast cancer cells in vivo [116]. Interestingly, this study reported that ALDH1A1 was the main ALDH isoenzyme determining of ALDEFLUOR $^{\mathrm{TM}}$ assay activity.

\section{Association of ALDH and metastasis in clinical tissue samples}

The association of ALDH and metastases in the clinical setting has been of interest since the late 1980s, when Marselos et al. showed increased enzymatic activity of ALDH (no isoform specified) in metastatic lesions from colon cancer compared with normal adjacent tissue [117]. This study would contrast with another early publication indicating that ALDH activity was not elevated in the serum of patients with metastatic hepatic cancer when compared with serum of patients with non-metastatic cancers [118]. ALDH expression has been assessed in matched primary tumor and metastases tissues in breast cancer [119], colorectal cancer [94, 120, 121], pancreatic cancer [112], and hepatic cancer [95]. The majority of these reports have shown a positive correlation between ALDH1 expression (ALDH1A1 as per [12] ) and metastasis. However, these results should be interpreted with caution due to technical and ethical limitations of working with metastatic tissue, including small numbers of samples analyzed and lack of consistency in staining and scoring methods. For example, diverse grading scales have been used in these studies to score ALDH staining in pathological specimens, including dichotomous scales and continuous scales with diverse cutoff points. This lack of consistency contrasts with the standardized in vivo functional evaluation of ALDH activity using the ALDEFLUOR $^{\mathrm{TM}}$ assay. In a recent study using matched colon primary tumor and metastases, Fitzgerald et al. reported ALDH1 (ALDH1A1 as per [12] ) as a predictor of poor clinical outcome [94], in direct contrast with an earlier study that had found a negative correlation [120]. In a study that might shed light in this controversy, using nonmatched primary tumor and metastases in colorectal cancer tissues, only homogeneous and intense expression of ALDH1A1 was correlated with metastasis [122].

In addition to ALDH activity/expression in tumor cells, ALDH expression has been recently also been observed in tumor-associated endothelial cells (TEC) from melanoma and oral cancers in vivo. TEC were shown to exhibit increased expression of angiogenic factors and angiogenic behavior in vitro, suggesting that there might be an ALDHmediated CSC activity in the tumor vascular compartment which in turn could promote tumor cell escape to the intravascular space [123].

\section{ALDH in circulating tumor cells (CTCs) and disseminated tumor cells (DTCs)}

The detection of circulating tumor cells (CTCs) in blood and disseminated tumor cells (DTCs) in bone marrow has been associated with the presence of clinically relevant metastatic disease and poor clinical outcome for a diverse group of solid tumors [124-127]. However, given the high inefficiency of the metastatic cascade, it has been hypothesized that CTCs and/or DTCs may contain sub-populations of cells with enhanced capacity to initiate and maintain growth and give rise to clinically relevant metastases. The biological characteristics and markers of metastasis-initiating CTCs and DTCs are not completely understood. The preclinical and clinical data reviewed above indicate that ALDH is 
Fig. 1 Molecular mechanisms associated with ALDH in metastasis promotion. The molecular mechanisms underlying the increased tumorigenicity and metastatic capacity of ALDH ${ }^{\text {hi }}$ cancer cells involve diverse co-expressed molecular factors and signaling pathways. For example, in breast, ovarian, and pancreatic cancer, ALDH1A1 transcription has been shown to be regulated after binding of $\mathrm{C} / \mathrm{EBP} \beta, \beta$ catenin, or Smad-4 to the ALDH1A1 promoter sequences $(a, b)$. In breast cancer cells, Notch-induced deacetylation of ALDH1A1 can result in increased CSC capabilities (c). Taken together, these pathways influence downstream functional behaviors such as stem cell-related decisions regarding proliferation and cell fate, epithelial-to-mesenchymal transition, retinoic acid synthesis, hypoxia, DNA damage response, cytokine and RTK signaling activation, and cell migration $(d)$, all of which may contribute to the role of $\mathrm{ALDH}^{\mathrm{hi}}$ cancer cells in metastasis promotion

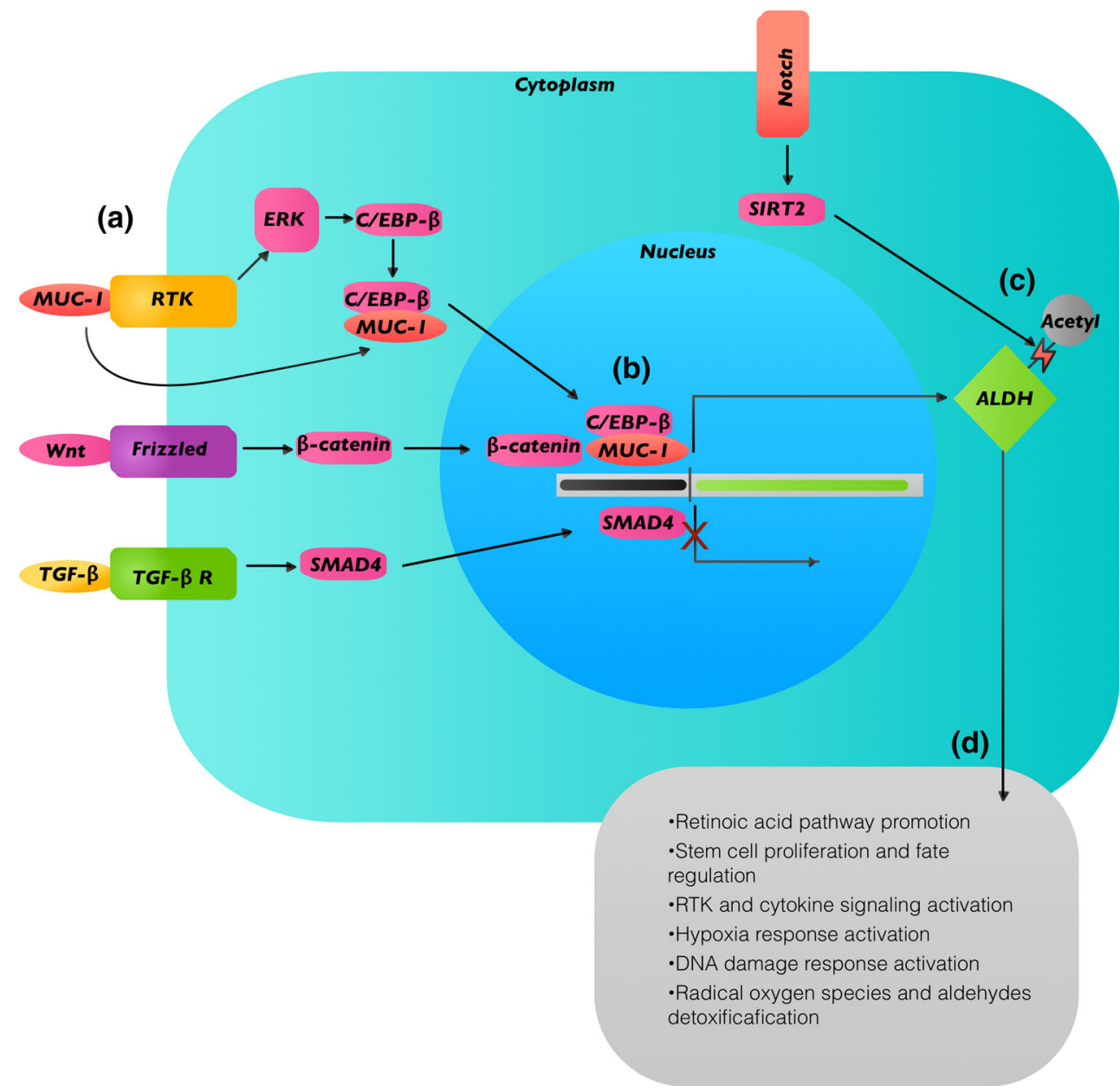

is not surprising given the nascent nature these type of studies, the small cohorts evaluated, the diversity of assays and parameters used to identify and isolate CTCs/DTCs, the inherent technical difficulties of isolating rare cells form clinical samples, and uncertainty about the biological characteristics of clinically relevant CTCs/DTCs that would allow their identification.

In one study involving 502 non-metastatic breast cancer patients, although ALDH was expressed in CTCs and DTCs in $14 \%$ of patients in the study cohort, it was not correlated with clinical prognosis or metastasis. In addition, this study showed no correlation of EMT markers in CTCs/DTCs with clinical outcome [134]. In another study, ALDH expression in primary breast tumors was not found to be correlated with the presence of CTCs, although it was correlated with clinical outcome in patients with nonmetastatic disease [135]. In an additional cohort of nonmetastatic breast cancer patients, although ALDH expression in DTCs was correlated with use of neoadjuvant chemotherapy and high tumor grade, it was not associated with metastatic recurrence [130]. Another study in a nonmetastatic breast cancer cohort showed that the CD44 CD24- phenotype in DTCs was a better clinical predictor 
of cancer progression relative to ALDH expression [136]. In general, studies evaluating ALDH expression in CTCs/ DTCs from patients with early non-metastatic breast cancer have shown less correlation of ALDH in CTCs/DTCs with clinical outcome and metastasis than studies performed in patients with metastatic disease [128, 129]. Therefore, although there is evidence supporting ALDH as a marker of CTC and DTC activity in advanced breast cancer, the functional and clinical implications of ALDH expression in CTCs/DTCs and eventual metastasis in breast cancer patients with early disease remains to be established. This suggests that the use of ALDH in CTCs/DTCs as a risk stratification marker might not be useful in patients with non-advanced disease. However, as described below, important technical considerations involving the methods to enrich CTCs/DTCs might change these results.

It is very important to note that in all the studies mentioned above, CTCs/DTCs were enriched using epithelial markers as primary criteria for their isolation. However, there is increasing evidence suggesting that a substantial proportion of CTCs/DTCs might display a more mesenchymal and aggressive phenotype that may not be picked up by standard CTC/DTC assays [124]. In fact, it has been shown that mesenchymal markers are over-expressed in CTCs and DTCs of metastatic and aggressive subtypes of breast cancer [137, 138]. Moreover, ALDH expression in CTCs has been correlated with poor clinical outcome, metastatic progression, and therapy response in patients with metastatic breast cancer [128, 129]. Interestingly, Liu et al. observed that breast CSCs transition between mesenchymal an epithelial states in order to fully develop metastasis, with ALDH participating during the epithelial and more proliferative phase of metastatic colonization in distant tissues. This suggests that ALDH may not be a key marker expressed during the intravascular and more mesenchymal phase of the metastatic cascade [139, 140]. Overall, the study of ALDH as a biomarker for metastasisinitiating cells and clinical outcome in CTCs/DTC is an emerging and promising field of research that is evolving at the pace of the refinement and validation of the technologies used to isolate this important group of cells navigating the metastatic cascade in the systemic circulation.

\section{Molecular mechanisms associated with ALDH in metastasis promotion}

The study of the molecular mechanisms underlying the increased tumorigenicity of $\mathrm{ALDH}^{\text {hi }}$ cells has revealed diverse co-expressed molecular factors and signaling pathways that might potentially also explain the observed increased metastatic behavior of $\mathrm{ALDH}^{\text {hi }}$ cancer cells. Since 2007, when the Hedgehog pathway was shown upregulated in $\mathrm{ALDH}^{\mathrm{hi}}$ pancreatic cancer cells [141], there has been accumulating evidence of signaling pathways associated with ALDH $^{\text {hi }}$ cells and their malignant activity (Summarized in Fig. 1). In particular, pathways involved in stem cell proliferation and cell fate [93, 101, 110, 141-147]; EMT [11, 36, 78, 81, 86, 90, 100, 110, 112, 146-155]; retinoic acid pathway [10, 89]; hypoxia [33, 79, $149,156]$ and DNA damage responses [143, 157, 158]; cytokine and receptor tyrosine kinase (RTK) [158-160] signaling activation; and cell migration [161], among others, have been implicated in promotion of aggressive behavior in ALDH ${ }^{\text {hi }}$ cells. Different isoforms of the Notch receptor have been found to be upregulated in $\mathrm{ALDH}^{\mathrm{hi}}$ cells from breast cancer, ovarian cancer, lung cancer, and osteosarcoma [81, 89, 100, 144, 145, 147, 148]. In addition, ALDH1A1 has been found to be correlated with Notch expression in lung and breast CSCs $[100,147]$. The Wnt- $\beta$ catenin pathway has been shown to be activated in cancer cells with high expression of ALDH1A1 and ALDH3A1 in prostate, ovarian, and liver cancer cells [86, 90, 110]; and the TGF $\beta$ pathway has been reported to facilitate therapy resistance in $\mathrm{ALDH}^{\mathrm{hi}}$ breast cancer cells, and to be involved in expression of ALDH1A1 in cholangiocarcinoma and pancreatic cancer [90, 103, 151, 152].

Interestingly, for some of these signaling pathways, the evidence suggests dualistic roles in metastasis depending on the cell context. For example, $\mathrm{Li}$ et al. reported that ALDH1A1 was involved in lung CSC activity via suppression of the Notch/CDK2/CCNE pathway [101], and, in other study, it was found that Nodal had a tumor suppressor function in $\mathrm{ALDH}^{\mathrm{hi}}$ cells via the activation of TGF $\beta$ pathway [150]. It is of note that there is evidence supporting a more complex model of metastasis navigation in which not only the EMT process but also the mesenchymal-to epithelial-transition (MET) processes are both critical for forming clinically relevant metastases [139, 140]. In this regard, research from two independent groups has shown that ALDH may be a marker and potential mechanistic promoter of a more proliferative/epithelial CSC phenotype via MET, while CD44 may, in contrast, be a marker of a more invasive subpopulation of migratory/ mesenchymal CSCs via EMT $[78,146]$. In addition, Marcato et al. have reported that ALDH1A3 may have a dual role in breast cancer metastasis promotion depending in the epigenetic cell context through differential retinoic acid signaling [10].

\section{Therapeutic potential of targeting ALDH in metastasis treatment and prevention}

Although there are relatively few studies assessing the impact of pharmacological or immune targeting of ALDH on metastasis in vivo, the majority of them are consistent in reporting a decrease of metastatic burden after targeting of 
ALDH. It has been shown that after treatment with the ALDH inhibitors DEAB and the novel A37 compound, there is a decreased metastatic activity in murine models of breast and ovarian cancer [33, 90]. It has also been demonstrated that CSC targeting with ALDH1A1-specific $\mathrm{CD}^{+} \mathrm{T}$ cells is followed by decreased spontaneous metastatic burden of HNSCC, pancreatic, and breast cancer cells in vivo [116]. Treatment with RA results in downregulation of ALDH1A1/ALDH3A1 expression or decreased ALDEFLOUR $^{\mathrm{TM}}$ activity $[28,42,89]$, and, in one recent study it has been reported that there is a reduction of in vitro metastatic behavior and reduction of xenograft growth of ovarian cancer cells after RA treatment [89]. However, Marcato et al. have reported that RA treatment has dual effects in a mouse model of human breast cancer metastasis depending on the cell epigenetic context [10].

The small molecule compound disulfiram has been found to display tumor inhibitory activity attributed to different properties, including ALDH1A1 inhibition [35, 162, 163], inhibition of proteasome activity [164, 165], prevention of NF- $\kappa B$ translocation [165, 166], induction of reactive oxygen species generation $[167,168]$, blockade of the PI3K/PTEN/AKT signaling pathway [169], inactivation of tumor-associated enzymes [170-172], and suppression of metastasis-associated gene expression [170, 171, 173]. Interestingly, it has been reported that disulfiram may have a therapeutic role in the metastatic setting. In one study, cell growth of metastatic osteosarcoma patient-derived cells was significantly decreased after disulfiram treatment in vitro [85]. In another study, cell growth was significantly decreased after disulfiram treatment of a metastatic murine osteosarcoma cell line in vitro [36]. It has also been reported that treatment with this compound decreases spontaneous lung metastatic burden in a syngeneic preclinical model of metastatic murine breast cancer [174]. In addition, a recent Phase IIb clinical trial found that addition of disulfiram to chemotherapy was well tolerated and appears to improve survival in newly diagnosed patients with metastatic non-small cell lung cancer [175]. Currently two clinical trials are evaluating the effect of disulfiram in treating glioblastoma multiforme (NCT01907165 and NCT01777919; www.clinicaltrials.gov).

The multiplicity of ALDH isoforms and its widespread tissue/tumor distribution, combined with differential epigenetic landscapes and inconsistency among parameters evaluated in small cohort trials may explain discrepancies observed between preclinical and clinical outcomes. Moreover, selective druggability of different ALDH isoforms is a formidable pharmacological challenge that may also contribute to conflicting results. Physiological concentrations of ALDH are most highly expressed in kidney and liver, which in turn limits the use of nonspecific inhibitors of ALDH that may result in toxic side-effects in patients. In addition, the enzymatic oxidative reaction carried out by different ALDH isoforms is highly nonspecific. For example, the ALDH substrate BAA has been found to be metabolized by different ALDH isoenzymes, including ALDH1A1, 1A2, 1A3, 2, 3A1, and 7 [4, 39, 67, 85]. Thus, there are important biochemical barriers to device a specific ALDH family or isoform inhibitor.

Rationalized small molecule discovery has been proposed as a viable methodology to surmount these difficulties and has been successfully employed to target specific aldehyde oxidases of the cytochrome P450 family in cancer cells [176-179]. An array of new generation isoform-specific ALDH inhibitors are under development. Among them, duocarmycin analogues stand out due to their ultra-high alkylating potency and additional ability to specifically target ALDH1A1 [12]. Therefore, it is expected that novel, potent, and isoform-specific ALDH inhibitors could enter the pipeline of experimental and clinical assessment in cancer therapy in the coming years. Taken together, these results underscore the potential of ALDH as a therapeutic target against metastasis.

\section{Conclusions and future perspectives}

Tumors are heterogeneous at the genetic, epigenetic, and tumorigenic level. There is substantial evidence indicating that tumor cells with stem-like capabilities are responsible, at least in part, for heterogeneity at the tumorigenic and metastatic level. ALDH stands out among the expansive and diverse group of CSC markers because of its widespread association with different types of solid tumors and the multiplicity of its biological functions, including retinoic acid signaling, antioxidant protection, osmoregulation, drug metabolism, and structural support. However, validation of ALDH as a prognostic biomarker and/or therapeutic target in the clinical setting has not yet come fully to fruition. Moving forward, it is critical that future studies include better standardization of ALDH identification and scoring methods, patient characteristics, and cohort sizes. In addition, more attention must be drawn to the study of the therapeutic effects of ALDH isoenzyme inhibitors in CTCs, DTCs, and metastatic and migratory activity. We believe that only a consistent preclinical and clinical approach revolving around CSC-mediated metastasis and therapy resistance will reveal the therapeutic and biomarker potential of ALDH in solid tumors.

In conclusion, it is clear that ALDH is not only a marker for aggressive stem-like and metastatic cells, but that it is also mechanistically involved in these behaviors. Hence, the study of ALDH as a biomarker and functional mediator of metastasis in vivo is a promissory field for discovering targets that might interfere with solid tumor progression. 
However, with the heterogeneity of ALDH isoforms described as CSC markers in different tumor types, and the newly described cell context dependent tumorigenic function of ALDH, it is likely that different isoforms may contribute differently to metastasis in different types of solid tumors. Moreover, given that it has been shown that other isoenzymes besides ALDH1A1 and ALDH1A3 are responsible for the activity reported in the ALDEFLUOR $^{\mathrm{TM}}$ assay, and the experimental evidence supporting multi-enzyme isoform participation in the same tumor, it is also likely that more than one ALDH isoform may be contributing to progression within the same tumor. Continued intensive investigation into the functional contribution of ALDH to cancer progression and metastasis will be important for tackling the enormous therapeutic challenge that such diverse landscape imposes.

Acknowledgments We thank members of our laboratory and our collaborators for their research work and helpful discussions. The authors' research on ALDH and CSCs is supported by research grants from the Canadian Breast Cancer Foundation (Ontario Region) and donor support from John and Donna Bristol and Richard and Susanne Shaftoe through the London Health Sciences Foundation (to ALA). MR-T is the recipient of a Vanier Doctoral Scholarship from the Canadian Institutes of Health Research (CIHR). ALA is supported by a CIHR New Investigator Award and an Early Researcher Award from the Ontario Ministry of Research and Innovation.

\section{Compliance with ethical standards}

Conflict of interest The authors declare that they have no conflict of interest.

Open Access This article is distributed under the terms of the Creative Commons Attribution 4.0 International License (http://crea tivecommons.org/licenses/by/4.0/), which permits unrestricted use, distribution, and reproduction in any medium, provided you give appropriate credit to the original author(s) and the source, provide a link to the Creative Commons license, and indicate if changes were made.

\section{References}

1. Redig A, McAllister S (2013) Breast cancer as a systemic disease: a view of metastasis. J Internal Med 274(2):113-126

2. Chambers AF, Groom AC, MacDonald IC (2002) Metastasis: dissemination and growth of cancer cells in metastatic sites. Nat Rev Cancer 2(8):563-572

3. Lu J, Steeg PS, Price JE, Krishnamurthy S, Mani SA, Reuben J, Cristofanilli M, Dontu G, Bidaut L, Valero V (2009) Breast cancer metastasis: challenges and opportunities. Cancer Res 69(12):4951-4953

4. Luzzi KJ, MacDonald IC, Schmidt EE, Kerkvliet N, Morris VL, Chambers AF, Groom AC (1998) Multistep nature of metastatic inefficiency: dormancy of solitary cells after successful extravasation and limited survival of early micrometastases. Am J Pathol 153(3):865-873

5. Ma I, Allan AL (2011) The role of human aldehyde dehydrogenase in normal and cancer stem cells. Stem Cell Rev 7(2):292-306
6. Beck B, Blanpain C (2013) Unravelling cancer stem cell potential. Nat Rev Cancer 13(10):727-738

7. Croker AK, Goodale D, Chu J, Postenka C, Hedley BD, Hess DA, Allan AL (2009) High aldehyde dehydrogenase and expression of cancer stem cell markers selects for breast cancer cells with enhanced malignant and metastatic ability. J Cell Mol Med 13(8B):2236-2252

8. Charafe-Jauffret E, Ginestier C, Iovino F, Wicinski J, Cervera N, Finetti P, Hur MH, Diebel ME, Monville F, Dutcher J, Brown M, Viens P, Xerri L, Bertucci F, Stassi G, Dontu G, Birnbaum D, Wicha MS (2009) Breast cancer cell lines contain functional cancer stem cells with metastatic capacity and a distinct molecular signature. Cancer Res 69(4):1302-1313

9. Marcato P, Dean CA, Pan D, Araslanova R, Gillis M, Joshi M, Helyer L, Pan L, Leidal A, Gujar S, Giacomantonio CA, Lee PW (2011) Aldehyde dehydrogenase activity of breast cancer stem cells is primarily due to isoform ALDH1A3 and its expression is predictive of metastasis. Stem Cells 29(1):32-45

10. Marcato P, Dean CA, Liu RZ, Coyle KM, Bydoun M, Wallace M, Clements D, Turner C, Mathenge EG, Gujar SA, Giacomantonio CA, Mackey JR, Godbout R, Lee PW (2015) Aldehyde dehydrogenase $1 \mathrm{~A} 3$ influences breast cancer progression via differential retinoic acid signaling. Mol Oncol 9(1):17-31

11. van den Hoogen C, van der Horst G, Cheung H, Buijs JT, Pelger RC, van der Pluijm G (2011) The aldehyde dehydrogenase enzyme 7A1 is functionally involved in prostate cancer bone metastasis. Clin Exp Metastasis 28(7):615-625

12. Pors K, Moreb JS (2014) Aldehyde dehydrogenases in cancer: an opportunity for biomarker and drug development? Drug Discov Today 19(12):1953-1963

13. Alison MR, Guppy NJ, Lim SM, Nicholson LJ (2010) Finding cancer stem cells: are aldehyde dehydrogenases fit for purpose? J Pathol 222(4):335-344

14. Vasiliou V, Thompson DC, Smith C, Fujita M, Chen Y (2013) Aldehyde dehydrogenases: from eye crystallins to metabolic disease and cancer stem cells. Chem Biol Interact 202(1-3):2-10

15. Charafe-Jauffret E, Ginestier C, Iovino F, Tarpin C, Diebel M, Esterni B, Houvenaeghel G, Extra JM, Bertucci F, Jacquemier J, Xerri L, Dontu G, Stassi G, Xiao Y, Barsky SH, Birnbaum D, Viens P, Wicha MS (2010) Aldehyde dehydrogenase 1-positive cancer stem cells mediate metastasis and poor clinical outcome in inflammatory breast cancer. Clin Cancer Res 16(1):45-55

16. Koppaka V, Thompson DC, Chen Y, Ellermann M, Nicolaou KC, Juvonen RO, Petersen D, Deitrich RA, Hurley TD, Vasiliou V (2012) Aldehyde dehydrogenase inhibitors: a comprehensive review of the pharmacology, mechanism of action, substrate specificity, and clinical application. Pharmacol Rev 64(3):520-539

17. Mitchell DY, Petersen DR (1987) The oxidation of $\alpha-\beta$ unsaturated aldehydic products of lipid peroxidation by rat liver aldehyde dehydrogenases. Toxicol Appl Pharm 87(3):403-410

18. Lindahl R, Petersen DR (1991) Lipid aldehyde oxidation as a physiological role for class 3 aldehyde dehydrogenases. Biochem Pharm 41(11):1583-1587

19. Singh S, Brocker C, Koppaka V, Chen Y, Jackson BC, Matsumoto A, Thompson DC, Vasiliou V (2013) Aldehyde dehydrogenases in cellular responses to oxidative/electrophilic stress. Free Radic Biol Med 56:89-101

20. Coyle K, Sultan M, Thomas M, Vaghar-Kashani A, Marcato P (2013) Retinoid signaling in cancer and its promise for therapy. J Carcinog Mutagen S 7:16-18

21. Januchowski R, Wojtowicz K, Zabel M (2013) The role of aldehyde dehydrogenase (ALDH) in cancer drug resistance. Biomed Pharm 67(7):669-680

22. Marchitti SA, Brocker C, Stagos D, Vasiliou V (2008) NonP450 aldehyde oxidizing enzymes: the aldehyde dehydrogenase superfamily. Expert Opin Drug Metab Toxicol 4(6):697-720 
23. Chute JP, Muramoto GG, Whitesides J, Colvin M, Safi R, Chao NJ, McDonnell DP (2006) Inhibition of aldehyde dehydrogenase and retinoid signaling induces the expansion of human hematopoietic stem cells. Proc Nat Acad Sci USA 103(31):11707-11712

24. Tonge PD, Andrews PW (2010) Retinoic acid directs neuronal differentiation of human pluripotent stem cell lines in a non-cellautonomous manner. Differentiation 80(1):20-30

25. Z-y Su, Li Y, X-1 Zhao, Zhang M (2010) All-trans retinoic acid promotes smooth muscle cell differentiation of rabbit bone marrow-derived mesenchymal stem cells. J Zhejiang Univ Sci B 11(7):489-496

26. Simandi Z, Balint BL, Poliska S, Ruhl R, Nagy L (2010) Activation of retinoic acid receptor signaling coordinates lineage commitment of spontaneously differentiating mouse embryonic stem cells in embryoid bodies. FEBS Lett 584(14): 3123-3130

27. Ren M, Pozzi S, Bistulfi G, Somenzi G, Rossetti S, Sacchi N (2005) Impaired retinoic acid (RA) signal leads to RAR $\beta 2$ epigenetic silencing and RA resistance. Mol Cell Biol 25(23):10591-10603

28. Croker AK, Allan AL (2012) Inhibition of aldehyde dehydrogenase (ALDH) activity reduces chemotherapy and radiation resistance of stem-like ALDHhiCD44(+) human breast cancer cells. Breast Cancer Res Treat 133(1):75-87

29. Li X, Wan L, Geng J, Wu C-L, Bai X (2012) Aldehyde dehydrogenase $1 \mathrm{~A} 1$ possesses stem-like properties and predicts lung cancer patient outcome. J Thoracic Oncol 7(8):1235-1245

30. Moreb JS, Baker HV, Chang LJ, Amaya M, Lopez MC, Ostmark B, Chou W (2008) ALDH isozymes downregulation affects cell growth, cell motility and gene expression in lung cancer cells. Mol Cancer 7:87

31. Kakizuka A, Miller W, Umesono K, Warrell R, Frankel S, Murty V, Dmitrovsky E, Evans R (1991) Chromosomal translocation $\mathrm{t}(15 ; 17)$ in human acute promyelocytic leukemia fuses RAR $\alpha$ with a novel putative transcription factor, PML. Cell 66(4):663-674

32. de Thé H, Lavau C, Marchio A, Chomienne C, Degos L, Dejean A (1991) The PML-RAR $\alpha$ fusion mRNA generated by the $t$ (15; 17) translocation in acute promyelocytic leukemia encodes a functionally altered RAR. Cell 66(4):675-684

33. Kim R-J, Park J-R, Roh K-J, Choi A-R, Kim S-R, Kim P-H, Yu JH, Lee JW, Ahn S-H, Gong G (2013) High aldehyde dehydrogenase activity enhances stem cell features in breast cancer cells by activating hypoxia-inducible factor- $2 \alpha$. Cancer Lett 333(1):18-31

34. Mizuno T, Suzuki N, Makino H, Furui T, Morii E, Aoki H, Kunisada T, Morishige K (2015) Cancer stem-like cells of ovarian clear cell carcinoma are enriched in the ALDH-high population associated with an accelerated scavenging system in reactive oxygen species. Gynecol Oncol 137(2):299-305

35. Liu P, Brown S, Goktug T, Channathodiyil P, Kannappan V, Hugnot J, Guichet P, Bian X, Armesilla A, Darling J (2012) Cytotoxic effect of disulfiram/copper on human glioblastoma cell lines and ALDH-positive cancer-stem-like cells. Br J Cancer 107(9):1488-1497

36. Mu X, Isaac C, Schott T, Huard J, Weiss K (2013) Rapamycin inhibits ALDH activity, resistance to oxidative stress, and metastatic potential in murine osteosarcoma cells. Sarcoma 2013:480713

37. Vasiliou V, Nebert DW (2005) Analysis and update of the human aldehyde dehydrogenase (ALDH) gene family. Hum Genom 2(2):138

38. Jean E, Laoudj-Chenivesse D, Notarnicola C, Rouger K, Serratrice N, Bonnieu A, Gay S, Bacou F, Duret C, Carnac G (2011) Aldehyde dehydrogenase activity promotes survival of human muscle precursor cells. J Cell Mol Med 15(1):119-133
39. Kitahara O, Katagiri T, Tsunoda T, Harima Y, Nakamura Y (2002) Classification of sensitivity or resistance of cervical cancers to ionizing radiation according to expression profiles of 62 genes selected by cDNA microarray analysis. Neoplasia 4(4):295-303

40. Sladek NE, Kollander R, Sreerama L, Kiang DT (2002) Cellular levels of aldehyde dehydrogenases (ALDH1A1 and ALDH3A1) as predictors of therapeutic responses to cyclophosphamidebased chemotherapy of breast cancer: a retrospective study. Rational individualization of oxazaphosphorine-based cancer chemotherapeutic regimens. Cancer Chemother Pharmacol 49 (4):309-321

41. Russo JE, Hilton J (1988) Characterization of cytosolic aldehyde dehydrogenase from cyclophosphamide resistant L1210 cells. Cancer Res 48(11):2963-2968

42. Moreb JS, Gabr A, Vartikar GR, Gowda S, Zucali JR, Mohuczy D (2005) Retinoic acid down-regulates aldehyde dehydrogenase and increases cytotoxicity of 4-hydroperoxycyclophosphamide and acetaldehyde. J Pharmacol Exper Ther 312(1):339-345

43. Moreb J, Zucali J, Zhang Y, Colvin M, Gross M (1992) Role of aldehyde dehydrogenase in the protection of hematopoietic progenitor cells from 4-hydroperoxycyclophosphamide by interleukin $1 \beta$ and tumor necrosis factor. Cancer Res 52(7): 1770-1774

44. Honoki K, Fujii H, Kubo A, Kido A, Mori T, Tanaka Y, Tsujiuchi T (2010) Possible involvement of stem-like populations with elevated ALDH1 in sarcomas for chemotherapeutic drug resistance. Oncol Rep 24(2):501-505

45. Landen CN, Goodman B, Katre AA, Steg AD, Nick AM, Stone RL, Miller LD, Mejia PV, Jennings NB, Gershenson DM (2010) Targeting aldehyde dehydrogenase cancer stem cells in ovarian cancer. Mol Cancer Ther 9(12):3186-3199

46. Kawasoe M, Yamamoto Y, Okawa K, Funato T, Takeda M, Hara T, Tsurumi H, Moriwaki H, Arioka Y, Takemura M (2013) Acquired resistance of leukemic cells to AraC is associated with the upregulation of aldehyde dehydrogenase 1 family member A2. Exp Hematol 41(7):597-603 e592

47. Lee DH, Chung K, Song J-A, T-h Kim, Kang H, Huh JH, S-g Jung, Ko JJ, An HJ (2010) Proteomic identification of paclitaxel-resistance associated hnRNP A2 and GDI 2 proteins in human ovarian cancer cells. J Proteome Res 9(11):5668-5676

48. Stewart M, Malek K, Crabb DW (1996) Distribution of messenger RNAs for aldehyde dehydrogenase 1, aldehyde dehydrogenase 2, and aldehyde dehydrogenase 5 in human tissues. J Investig Med 44(2):42-46

49. Dipple K, Crabb D (1993) The mitochondrial aldehyde dehydrogenase gene resides in an HTF island but is expressed in a tissue-specific manner. Biochem Biophys Res Commun 193(1): 420-427

50. Storms RW, Trujillo AP, Springer JB, Shah L, Colvin OM, Ludeman SM, Smith C (1999) Isolation of primitive human hematopoietic progenitors on the basis of aldehyde dehydrogenase activity. Proc Nat Acad of Sci USA 96(16):9118-9123

51. Corti S, Locatelli F, Papadimitriou D, Donadoni C, Salani S, Del Bo R, Strazzer S, Bresolin N, Comi GP (2006) Identification of a primitive brain-derived neural stem cell population based on aldehyde dehydrogenase activity. Stem Cells 24(4):975-985

52. Ginestier C, Hur MH, Charafe-Jauffret E, Monville F, Dutcher J, Brown M, Jacquemier J, Viens P, Kleer CG, Liu S, Schott A, Hayes D, Birnbaum D, Wicha MS, Dontu G (2007) ALDH1 is a marker of normal and malignant human mammary stem cells and a predictor of poor clinical outcome. Cell Stem Cell 1(5):555-567

53. Pearce DJ, Bonnet D (2007) The combined use of Hoechst efflux ability and aldehyde dehydrogenase activity to identify 
murine and human hematopoietic stem cells. Exp Hematol 35(9):1437-1446

54. Levi BP, Yilmaz ÖH, Duester G, Morrison SJ (2009) Aldehyde dehydrogenase 1a1 is dispensable for stem cell function in the mouse hematopoietic and nervous systems. Blood 113(8):1670-1680

55. Muramoto GG, Russell JL, Safi R, Salter AB, Himburg HA, Daher P, Meadows SK, Doan P, Storms RW, Chao NJ (2010) Inhibition of aldehyde dehydrogenase expands hematopoietic stem cells with radioprotective capacity. Stem Cells 28(3): 523-534

56. Armstrong L, Stojkovic M, Dimmick I, Ahmad S, Stojkovic P, Hole N, Lako M (2004) Phenotypic characterization of murine primitive hematopoietic progenitor cells isolated on basis of aldehyde dehydrogenase activity. Stem Cells 22(7):1142-1151

57. Zhuang X, Zhang W, Chen Y, Han X, Li J, Zhang Y, Zhang Y, Zhang S, Liu B (2012) Doxorubicin-enriched, ALDHbr mouse breast cancer stem cells are treatable to oncolytic herpes simplex virus type 1. BMC Cancer 12(1):549

58. Wang SH, Lu L, Fan Y, Wicha MS, Cao Z, Chang AE, J-c Xia, Baker JR Jr, Li Q (2014) Characterization of a novel transgenic mouse tumor model for targeting HER2+ cancer stem cells. Int J Biol Sci 10(1):25

59. Vaidyanathan G, Song H, Affleck D, McDougald DL, Storms RW, Zalutsky MR, Chin BB (2009) Targeting aldehyde dehydrogenase: a potential approach for cell labeling. Nucl Med Biol 36(8):919-929

60. Huang EH, Hynes MJ, Zhang T, Ginestier C, Dontu G, Appelman H, Fields JZ, Wicha MS, Boman BM (2009) Aldehyde dehydrogenase 1 is a marker for normal and malignant human colonic stem cells (SC) and tracks SC overpopulation during colon tumorigenesis. Cancer Res 69(8):3382-3389

61. Isfoss BL, Holmqvist B, Jernström H, Alm P, Olsson H (2013) Women with familial risk for breast cancer have an increased frequency of aldehyde dehydrogenase expressing cells in breast ductules. BMC Clin Pathol 13(1):28

62. Khoury T, Ademuyiwa FO, Chandraseekhar R, Jabbour M, DeLeo A, Ferrone S, Wang Y, Wang X (2012) Aldehyde dehydrogenase $1 \mathrm{~A} 1$ expression in breast cancer is associated with stage, triple negativity, and outcome to neoadjuvant chemotherapy. Mod Pathol 25(3):388-397

63. Moreb JS, Ucar D, Han S, Amory JK, Goldstein AS, Ostmark B, Chang LJ (2012) The enzymatic activity of human aldehyde dehydrogenases $1 \mathrm{~A} 2$ and 2 (ALDH1A2 and ALDH2) is detected by Aldefluor, inhibited by diethylaminobenzaldehyde and has significant effects on cell proliferation and drug resistance. Chem Biol Interact 195(1):52-60

64. Marcato P, Dean CA, Giacomantonio CA, Lee PW (2011) Aldehyde dehydrogenase: its role as a cancer stem cell marker comes down to the specific isoform. Cell Cycle 10(9):1378-1384

65. Luo Y, Dallaglio K, Chen Y, Robinson WA, Robinson SE, McCarter MD, Wang J, Gonzalez R, Thompson DC, Norris DA (2012) ALDH1A isozymes are markers of human melanoma stem cells and potential therapeutic targets. Stem Cells 30(10):2100-2113

66. Xia P (2014) Surface markers of cancer stem cells in solid tumors. Curr Stem Cell Res Ther 9(2):102-111

67. Tirino V, Desiderio V, Paino F, De Rosa A, Papaccio F, La Noce M, Laino L, De Francesco F, Papaccio G (2013) Cancer stem cells in solid tumors: an overview and new approaches for their isolation and characterization. FASEB 27(1):13-24

68. Fabian A, Vereb G, Szöllösi J (2013) The hitchhikers guide to cancer stem cell theory: markers, pathways and therapy. Cytom A 83(1):62-71

69. Keysar SB, Jimeno A (2010) More than markers: biological significance of cancer stem cell-defining molecules. Mol Cancer Ther 9(9):2450-2457
70. Visvader JE, Lindeman GJ (2008) Cancer stem cells in solid tumours: accumulating evidence and unresolved questions. Nat Rev Cancer 8(10):755-768

71. Pouliot N, Pearson HB, Burrows A (2000) Investigating metastasis using in vitro platforms. In: Madame Curie Bioscience Database [Internet]. Austin (TX): Landes Bioscience; 2000. http://www.ncbi.nlm.nih.gov/books/NBK100379/

72. Brooks SA, Schumacher U (2001) Metastasis research protocols, vol 58. Springer, Berlin

73. Grimshaw MJ, Cooper L, Papazisis K, Coleman JA, Bohnenkamp HR, Chiapero-Stanke L, Taylor-Papadimitriou J, Burchell JM (2008) Mammosphere culture of metastatic breast cancer cells enriches for tumorigenic breast cancer cells. Breast Cancer Res 10(3):R52

74. Soritău O, Tomuleasa C, Pall E, Virág P, Fischer-Fodor E, Foris V (2010) Enhanced chemoresistance and tumor sphere formation as a laboratory model for peritoneal micrometastasis in epithelial ovarian cancer. Rom J Morphol Embryol 51(2):259-264

75. Cioce M, Gherardi S, Viglietto G, Strano S, Blandino G, Muti P, Ciliberto G (2010) Mammosphere-forming cells from breast cancer cell lines as a tool for the identification of CSC-like-and early progenitor-targeting drugs. Cell Cycle 9(14):2950-2959

76. Kerbel R, Kobayashi H, Graham CH (1994) Intrinsic or acquired drug resistance and metastasis: are they linked phenotypes? J Cell Biochem 56(1):37-47

77. Wong ST, Goodin S (2009) Overcoming drug resistance in patients with metastatic breast cancer. Pharmacotherapy 29(8): 954-965

78. Liu S, Cong Y, Wang D, Sun Y, Deng L, Liu Y, Martin-Trevino R, Shang L, McDermott SP, Landis MD, Hong S, Adams A, D'Angelo R, Ginestier C, Charafe-Jauffret E, Clouthier SG, Birnbaum D, Wong ST, Zhan M, Chang JC, Wicha MS (2014) Breast cancer stem cells transition between epithelial and mesenchymal states reflective of their normal counterparts. Stem Cell Rep 2(1):78-91

79. Liao J, Qian F, Tchabo N, Mhawech-Fauceglia P, Beck A, Qian Z, Wang X, Huss WJ, Lele SB, Morrison CD (2014) Ovarian cancer spheroid cells with stem cell-like properties contribute to tumor generation, metastasis and chemotherapy resistance through hypoxia-resistant metabolism. PLoS One 9(1):e84941

80. Kuroda T, Hirohashi Y, Torigoe T, Yasuda K, Takahashi A, Asanuma H, Morita R, Mariya T, Asano T, Mizuuchi M, Saito T, Sato N (2013) ALDH1-high ovarian cancer stem-like cells can be isolated from serous and clear cell adenocarcinoma cells, and ALDH1 high expression is associated with poor prognosis. PLoS One 8(6):e65158

81. Mu X, Isaac C, Greco N, Huard J, Weiss K (2013) Notch signaling is associated with ALDH activity and an aggressive metastatic phenotype in murine osteosarcoma cells. Front Oncol 3:143

82. Ajani J, Wang X, Song S, Suzuki A, Taketa T, Sudo K, Wadhwa R, Hofstetter W, Komaki R, Maru D (2014) ALDH-1 expression levels predict response or resistance to preoperative chemoradiation in resectable esophageal cancer patients. Mol Oncol 8(1):142-149

83. Reeves K, van der Pluijm G, Cecchini M, Eaton C, Hamdy F, Brown N (2013) The influence of tumour aldehyde dehydrogenase activity on prostate cancer cell metastatic potential and interaction with the bone endothelium in vivo. In: Proceedings of the physiological society, 2013. The Physiological Society

84. Tanei T, Morimoto K, Shimazu K, Kim SJ, Tanji Y, Taguchi T, Tamaki Y, Noguchi S (2009) Association of breast cancer stem cells identified by aldehyde dehydrogenase 1 expression with resistance to sequential Paclitaxel and epirubicin-based chemotherapy for breast cancers. Clin Cancer Res 15(12): 4234-4241 
85. Greco N, Schott T, Mu X, Rothenberg A, Voigt C, McGough RL 3rd, Goodman M, Huard J, Weiss KR (2014) ALDH activity correlates with metastatic potential in primary sarcomas of bone. J Cancer Ther 5(4):331-338

86. Cojoc M, Peitzsch C, Kurth I, Trautmann F, Kunz-Schughart LA, Telegeev GD, Stakhovsky EA, Walker JR, Simin K, Lyle S (2015) Aldehyde dehydrogenase is regulated by $\beta$-Catenin/TCF and promotes radioresistance in prostate cancer progenitor cells. Cancer Res 75(7):1482-1494

87. Charafe-Jauffret E, Ginestier C, Bertucci F, Cabaud O, Wicinski J, Finetti P, Josselin E, Adelaide J, Nguyen T-T, Monville F (2013) ALDH1-positive cancer stem cells predict engraftment of primary breast tumors and are governed by a common stem cell program. Cancer Res 73(24):7290-7300

88. Li D, Zhang T, Gu W, Li P, Cheng X, Tong T, Wang W (2015) The ALDH1 + subpopulation of the human NMFH-1 cell line exhibits cancer stem-like characteristics. Oncol Rep 33(5):2291-2298

89. Young M-J, Wu Y-H, Chiu W-T, Weng T-Y, Huang Y-F, Chou C-Y (2015) All-trans retinoic acid downregulates ALDH1-mediated stemness and inhibits tumour formation in ovarian cancer cells. Carcinogenesis 36:498-507 bgv018

90. Condello S, Morgan C, Nagdas S, Cao L, Turek J, Hurley T, Matei D (2015) $\beta$-Catenin-regulated ALDH1A1 is a target in ovarian cancer spheroids. Oncogene 34(18):2297-2308

91. Choi SA, Lee JY, Phi JH, Wang K-C, Park C-K, Park S-H, Kim S-K (2014) Identification of brain tumour initiating cells using the stem cell marker aldehyde dehydrogenase. Eur J Cancer 50(1):137-149

92. Soehngen E, Schaefer A, Koeritzer J, Huelsmeyer V, Zimmer C, Ringel F, Gempt J, Schlegel J (2014) Hypoxia upregulates aldehyde dehydrogenase isoform 1 (ALDH1) expression and induces functional stem cell characteristics in human glioblastoma cells. Brain Tumor Pathol 31(4):247-256

93. Yu C-C, Lo W-L, Chen Y-W, Huang P-I, Hsu H-S, Tseng L-M, Hung S-C, Kao S-Y, Chang C-J, Chiou SH (2010) Bmi-1 regulates snail expression and promotes metastasis ability in head and neck squamous cancer-derived ALDH1 positive cells. J Oncol 2011

94. Fitzgerald TL, Rangan S, Dobbs L, Starr S, Sigounas G (2014) The impact of Aldehyde dehydrogenase 1 expression on prognosis for metastatic colon cancer. J Surg Res 192(1):82-89

95. James MI, Howells LM, Karmokar A, Higgins JA, Greaves P, Cai H, Dennison A, Metcalfe M, Garcea G, Lloyd DM (2015) Characterization and propagation of tumor initiating cells derived from colorectal liver metastases: trials, tribulations and a cautionary note. PLoS One 10(2):e0117776

96. Larzabal L, El-Nikhely N, Redrado M, Seeger W, Savai R, Calvo A (2013) Differential effects of drugs targeting cancer stem cell (CSC) and non-CSC populations on lung primary tumors and metastasis. PLoS One 8(11):e79798

97. Liang D, Shi Y (2012) Aldehyde dehydrogenase-1 is a specific marker for stem cells in human lung adenocarcinoma. Med Oncol 29(2):633-639

98. Akunuru S, Zhai QJ, Zheng Y (2012) Non-small cell lung cancer stem/progenitor cells are enriched in multiple distinct phenotypic subpopulations and exhibit plasticity. Cell Death Dis 3(7): 352

99. Lin J, Liu X, Ding D (2015) Evidence for epithelial-mesenchymal transition in cancer stem-like cells derived from carcinoma cell lines of the cervix uteri. Int J Clin Exper Pathol $8(1): 847$

100. Sullivan JP, Spinola M, Dodge M, Raso MG, Behrens C, Gao B, Schuster K, Shao C, Larsen JE, Sullivan LA (2010) Aldehyde dehydrogenase activity selects for lung adenocarcinoma stem cells dependent on notch signaling. Cancer Res 70(23):9937-9948
101. Li Z, Xiang Y, Xiang L, Xiao Y, Li F, Hao P (2014) ALDH maintains the stemness of lung adenoma stem cells by suppressing the Notch/CDK2/CCNE pathway. PLoS One 9(3):e92669

102. Yang L, Ren Y, Yu X, Qian F, Bian BS, Xiao HL, Wang WG, Xu SL, Yang J, Cui W, Liu Q, Wang Z, Guo W, Xiong G, Yang K, Qian C, Zhang X, Zhang P, Cui YH, Bian XW (2014) ALDH1A1 defines invasive cancer stem-like cells and predicts poor prognosis in patients with esophageal squamous cell carcinoma. Mod Pathol 27(5):775-783

103. Hoshino Y, Nishida J, Katsuno Y, Koinuma D, Aoki T, Kokudo N, Miyazono K, Ehata S (2015) Smad4 decreases the population of pancreatic cancer-initiating cells through transcriptional repression of ALDH1A1. Am J Pathol 185(5):1457-1470

104. Wang K, Chen X, Zhan Y, Jiang W, Liu X, Wang X, Wu B (2013) Increased expression of ALDH1A1 protein is associated with poor prognosis in clear cell renal cell carcinoma. Med Oncol 30(2):1-9

105. Huang C-P, Tsai M-F, Chang T-H, Tang W-C, Chen S-Y, Lai H-H, Lin T-Y, Yang JC-H, Yang P-C, Shih J-Y (2013) ALDHpositive lung cancer stem cells confer resistance to epidermal growth factor receptor tyrosine kinase inhibitors. Cancer Lett 328(1):144-151

106. Yue L, Huang Z-M, Fong S, Leong S, Jakowatz JG, CharruyerReinwald A, Wei M, Ghadially R (2015) Targeting ALDH1 to decrease tumorigenicity, growth and metastasis of human melanoma. Melanoma Res 25(2):138-148

107. Jia J, Parikh H, Xiao W, Hoskins JW, Pflicke H, Liu X, Collins I, Zhou W, Wang Z, Powell J, Thorgeirsson SS, Rudloff U, Petersen GM, Amundadottir LT (2013) An integrated transcriptome and epigenome analysis identifies a novel candidate gene for pancreatic cancer. BMC Med Genomics 6:33

108. Mao P, Joshi K, Li J, Kim S-H, Li P, Santana-Santos L, Luthra S, Chandran UR, Benos PV, Smith L (2013) Mesenchymal glioma stem cells are maintained by activated glycolytic metabolism involving aldehyde dehydrogenase 1A3. Proc Nat Acad Sci 110(21):8644-8649

109. Yan J, De Melo J, Cutz J, Aziz T, Tang D (2014) Aldehyde dehydrogenase $3 \mathrm{~A} 1$ associates with prostate tumorigenesis. Br J Cancer 110(10):2593-2603

110. Calderaro J, Nault J-C, Bioulac-Sage P, Laurent A, Blanc J-F, Decaens T, Zucman-Rossi J (2014) ALDH3A1 is overexpressed in a subset of hepatocellular carcinoma characterised by activation of the Wnt/ß-catenin pathway. Virchows Arch 464(1):53-60

111. Fillmore CM, Kuperwasser C (2008) Human breast cancer cell lines contain stem-like cells that self-renew, give rise to phenotypically diverse progeny and survive chemotherapy. Breast Cancer Res 10(2):R25

112. Rasheed ZA, Yang J, Wang Q, Kowalski J, Freed I, Murter C, Hong S-M, Koorstra J-B, Rajeshkumar N, He X (2010) Prognostic significance of tumorigenic cells with mesenchymal features in pancreatic adenocarcinoma. J Nat Cancer Inst 102(5):340-351

113. van den Hoogen C, van der Horst G, Cheung H, Buijs JT, Pelger $\mathrm{RC}$, van der Pluijm G (2011) Integrin $\alpha \mathrm{v}$ expression is required for the acquisition of a metastatic stem/progenitor cell phenotype in human prostate cancer. Am J Pathol 179(5):2559-2568

114. van den Hoogen C, van der Horst G, Cheung H, Buijs JT, Lippitt JM, Guzman-Ramirez N, Hamdy FC, Eaton CL, Thalmann GN, Cecchini MG, Pelger RC, van der Pluijm G (2010) High aldehyde dehydrogenase activity identifies tumor-initiating and metastasis-initiating cells in human prostate cancer. Cancer Res 70(12):5163-5173

115. Sun S, Wang Z (2010) ALDH high adenoid cystic carcinoma cells display cancer stem cell properties and are responsible for mediating metastasis. Biochem Biophys Res Commun 396(4):843-848

116. Visus C, Wang Y, Lozano-Leon A, Ferris RL, Silver S, Szczepanski MJ, Brand RE, Ferrone CR, Whiteside TL, Ferrone 
S (2011) Targeting ALDHbright Human Carcinoma-Initiating Cells with ALDH1A1-Specific CD8+ T Cells. Clin Cancer Res 17(19):6174-6184

117. Marselos M, Michalopoulos G (1987) Changes in the pattern of aldehyde dehydrogenase activity in primary and metastatic adenocarcinomas of the human colon. Cancer Lett 34(1):27-37

118. Jelski W, Zalewski B, Szmitkowski M (2008) Alcohol dehydrogenase $(\mathrm{ADH})$ isoenzymes and aldehyde dehydrogenase (ALDH) activity in the sera of patients with liver cancer. J Clin Lab Anal 22(3):204-209

119. Shao J, C-p Pan, Wang M-w Wu, X-h Ma B (2013) Discordance of aldehyde dehydrogenase 1 and estrogen receptor expression between primary and metastatic focuses of breast cancer. Acta Anat Sin 2:224-228

120. Hessman CJ, Bubbers EJ, Billingsley KG, Herzig DO, Wong MH (2012) Loss of expression of the cancer stem cell marker aldehyde dehydrogenase 1 correlates with advanced-stage colorectal cancer. Am J Surg 203(5):649-653

121. Sreerama L, Sladek NE (1997) Cellular levels of class 1 and class 3 aldehyde dehydrogenases and certain other drug-metabolizing enzymes in human breast malignancies. Clin Cancer Res 3(11):1901-1914

122. Vogler T, Kriegl L, Horst D, Engel J, Sagebiel S, Schäffauer AJ, Kirchner T, Jung A (2012) The expression pattern of aldehyde dehydrogenase 1 (ALDH1) is an independent prognostic marker for low survival in colorectal tumors. Exp Mol Pathol 92(1):111-117

123. Ohmura-Kakutani H, Akiyama K, Maishi N, Ohga N, Hida Y, Kawamoto T, Iida J, Shindoh M, Tsuchiya K, Shinohara N (2014) Identification of tumor endothelial cells with high aldehyde dehydrogenase activity and a highly angiogenic phenotype. PLoS One 9(12):e113910

124. Lowes LE, Allan AL (2014) Recent advances in the molecular characterization of circulating tumor cells. Cancers 6(1):595-624

125. Giuliano M, Giordano A, Jackson S, De Giorgi U, Mego M, Cohen EN, Gao H, Anfossi S, Handy BC, Ueno NT (2014) Circulating tumor cells as early predictors of metastatic spread in breast cancer patients with limited metastatic dissemination. Breast Cancer Res 16(5):440

126. Baccelli I, Schneeweiss A, Riethdorf S, Stenzinger A, Schillert A, Vogel V, Klein C, Saini M, Bäuerle T, Wallwiener M (2013) Identification of a population of blood circulating tumor cells from breast cancer patients that initiates metastasis in a xenograft assay. Nat Biotechnol 31(6):539-544

127. Bednarz-Knoll N, Alix-Panabières C, Pantel K (2011) Clinical relevance and biology of circulating tumor cells. Breast Cancer Res 13(6):228

128. Aktas B, Tewes M, Fehm T, Hauch S, Kimmig R, KasimirBauer S (2009) Stem cell and epithelial-mesenchymal transition markers are frequently overexpressed in circulating tumor cells of metastatic breast cancer patients. Breast Cancer Res 11(4):R46

129. Gradilone A, Naso G, Raimondi C, Cortesi E, Gandini O, Vincenzi B, Saltarelli R, Chiapparino E, Spremberg F, Cristofanilli M (2011) Circulating tumor cells (CTCs) in metastatic breast cancer (MBC): prognosis, drug resistance and phenotypic characterization. Ann Oncol 22(1):86-92

130. Reuben JM, Lee BN, Gao H, Cohen EN, Mego M, Giordano A, Wang X, Lodhi A, Krishnamurthy S, Hortobagyi GN, Cristofanilli M, Lucci A, Woodward WA (2011) Primary breast cancer patients with high risk clinicopathologic features have high percentages of bone marrow epithelial cells with ALDH activity and CD44(+)CD24lo cancer stem cell phenotype. Eur J Cancer 47(10): 1527-1536

131. Theodoropoulos PA, Polioudaki H, Agelaki S, Kallergi G, Saridaki Z, Mavroudis D, Georgoulias V (2010) Circulating tumor cells with a putative stem cell phenotype in peripheral blood of patients with breast cancer. Cancer Lett 288(1):99-106

132. Zirvi KA, Hill GJ, Hill HZ (1986) Comparative studies of chemotherapy of human tumor cells in vitro by tritiated thymidine uptake inhibition and soft agar clonogenic assay. J Surg Oncol 31(2):123-126

133. Alonso-Alconada L, Muinelo-Romay L, Madissoo K, DiazLopez A, Krakstad C, Trovik J, Wik E, Hapangama D, Coenegrachts L, Cano A (2014) Molecular profiling of circulating tumor cells links plasticity to the metastatic process in endometrial cancer. Mol Cancer 13(1):223

134. Krawczyk N, Meier-Stiegen F, Banys M, Neubauer H, Ruckhaeberle E, Fehm T (2014) Expression of stem cell and epithelial-mesenchymal transition markers in circulating tumor cells of breast cancer patients. Biomed Res Int 2014:415721

135. Woodward WA, Krishnamurthy S, Lodhi A, Xiao L, Gong Y, Cristofanilli M, Buchholz TA, Lucci A (2014) Aldehyde dehydrogenase 1 immunohistochemical staining in primary breast cancer cells independently predicted overall survival but did not correlate with the presence of circulating or disseminated tumors cells. J Cancer 5(5):360

136. Giordano A, Gao H, Cohen E, Anfossi S, Khoury J, Hess K, Krishnamurthy S, Tin S, Cristofanilli M, Hortobagyi G (2013) Clinical relevance of cancer stem cells in bone marrow of early breast cancer patients. Ann Oncol: mdt223

137. Papadaki MA, Kallergi G, Zafeiriou Z, Manouras L, Theodoropoulos PA, Mavroudis D, Georgoulias V, Agelaki S (2014) Coexpression of putative stemness and epithelial-to-mesenchymal transition markers on single circulating tumour cells from patients with early and metastatic breast cancer. BMC Cancer 14(1):651

138. Giordano A, Gao H, Anfossi S, Cohen E, Mego M, Lee B-N, Tin S, De Laurentiis M, Parker CA, Alvarez RH (2012) Epithelialmesenchymal transition and stem cell markers in patients with HER2-positive metastatic breast cancer. Mol Cancer Ther 11(11):2526-2534

139. Tsai JH, Donaher JL, Murphy DA, Chau S, Yang J (2012) Spatiotemporal regulation of epithelial-mesenchymal transition is essential for squamous cell carcinoma metastasis. Cancer Cell 22(6):725-736

140. Ocaña OH, Córcoles R, Fabra Á, Moreno-Bueno G, Acloque H, Vega S, Barrallo-Gimeno A, Cano A, Nieto MA (2012) Metastatic colonization requires the repression of the epithelialmesenchymal transition inducer Prrx1. Cancer Cell 22(6): 709-724

141. Feldmann G, Dhara S, Fendrich V, Bedja D, Beaty R, Mullendore M, Karikari C, Alvarez H, Iacobuzio-Donahue C, Jimeno A (2007) Blockade of hedgehog signaling inhibits pancreatic cancer invasion and metastases: a new paradigm for combination therapy in solid cancers. Cancer Res 67(5):2187-2196

142. Ozbek E, Calik G, Otunctemur A, Aliskan T, Cakir S, Dursun M, Somay A (2012) Stem cell markers aldehyde dehydrogenase type 1 and nestin expressions in renal cell cancer. Archivio italiano di urologia, andrologia 84(1):7-11

143. Meng E, Mitra A, Tripathi K, Finan MA, Scalici J, McClellan S, da Silva LM, Reed E, Shevde LA, Palle K (2014) ALDH1A1 maintains ovarian cancer stem cell-like properties by altered regulation of cell cycle checkpoint and DNA repair network signaling. PLoS One 9(9):e107142

144. Suman S, Das T, Damodaran C (2013) Silencing NOTCH signaling causes growth arrest in both breast cancer stem cells and breast cancer cells. Br J Cancer 109(10):2587-2596

145. D'Angelo RC, Ouzounova M, Davis A, Choi D, Tchuenkam SM, Kim G, Luther T, Quraishi AA, Senbabaoglu Y, Conley SJ (2015) Notch reporter activity in breast cancer cell lines identifies a subset of cells with stem cell activity. Mol Cancer Ther 14(3):779-787 
146. Chen X, Lingala S, Khoobyari S, Nolta J, Zern MA, Wu J (2011) Epithelial mesenchymal transition and hedgehog signaling activation are associated with chemoresistance and invasion of hepatoma subpopulations. J Hepatol 55(4):838-845

147. Zhao D, Mo Y, Li M-T, Zou S-W, Cheng Z-L, Sun Y-P, Xiong Y, Guan K-L, Lei Q-Y (2014) NOTCH-induced aldehyde dehydrogenase $1 \mathrm{~A} 1$ deacetylation promotes breast cancer stem cells. J Clin Investig 124(12):5453-5465

148. Cui J, Li P, Liu X, Hu H, Wei W (2015) Abnormal expression of the Notch and Wnt/ $\beta$-catenin signaling pathways in stem-like ALDHhiCD44+ cells correlates highly with Ki-67 expression in breast cancer. Oncol Lett 9(4):1600-1606

149. Tiezzi DG, Clagnan WS, Mandarano LRM, de Sousa CB, Marana HRC, Tiezzi MG, de Andrade JM (2013) Expression of aldehyde dehydrogenase after neoadjuvant chemotherapy is associated with expression of hypoxia-inducible factors 1 and 2 alpha and predicts prognosis in locally advanced breast cancer. Clinics 68(5):592-598

150. Wang Y, Jiang Y, Tian T, Hori Y, Wada N, J-i Ikeda, Morii E (2013) Inhibitory effect of Nodal on the expression of aldehyde dehydrogenase 1 in endometrioid adenocarcinoma of uterus. Biochem Biophys Res Comm 440(4):731-736

151. Shuang Z-Y, Wu W-C, Xu J, Lin G, Liu Y-C, Lao X-M, Zheng L, Li S (2014) Transforming growth factor- $\beta 1$-induced epithelial-mesenchymal transition generates ALDH-positive cells with stem cell properties in cholangiocarcinoma. Cancer Lett 354(2):320-328

152. Bhola NE, Balko JM, Dugger TC, Kuba MG, Sánchez V, Sanders M, Stanford J, Cook RS, Arteaga CL (2013) TGF- $\beta$ inhibition enhances chemotherapy action against triple-negative breast cancer. J Clin Invest 123(3):1348

153. Wei L, Liu T-T, Wang H-H, Hong H-M, Yu AL, Feng H-P, Chang W-W (2011) Hsp27 participates in the maintenance of breast cancer stem cells through regulation of epithelial-mesenchymal transition and nuclear factor-kappaB. Breast Cancer Res 13(5):R101

154. Lee D, Lee JW (2015) Self-renewal and circulating capacities of metastatic hepatocarcinoma cells required for collaboration between TM4SF5 and CD44. BMB Rep 48(3):127

155. Qian X, Anzovino A, Kim S, Suyama K, Yao J, Hulit J, Agiostratidou G, Chandiramani N, McDaid H, Nagi C (2014) Ncadherin/FGFR promotes metastasis through epithelial-to-mesenchymal transition and stem/progenitor cell-like properties. Oncogene 33(26):3411-3421

156. Taiseer I, Samar AR, Abdelmonem H (2014) Immunohistochemical Expression of Aldehyde Dehydrogenase-1 and Hypoxia- Inducible Factor-1 alpha in Breast Cancer. Int $\mathbf{J}$ Adv Res 2(7):822-830

157. Serrano D, Bleau A-M, Fernandez-Garcia I, Fernandez-Marcelo T, Iniesta P, Ortiz-de-Solorzano C, Calvo A (2011) Inhibition of telomerase activity preferentially targets aldehyde dehydrogenase-positive cancer stem-like cells in lung cancer. Mol Cancer 10(96): 10.1186

158. Lin L, Fuchs J, Li C, Olson V, Bekaii-Saab T, Lin J (2011) STAT3 signaling pathway is necessary for cell survival and tumorsphere forming capacity in ALDH+/CD133+ stem celllike human colon cancer cells. Biochem Biophys Res Commun 416(3):246-251

159. Korkaya H, Paulson A, Iovino F, Wicha MS (2008) HER2 regulates the mammary stem/progenitor cell population driving tumorigenesis and invasion. Oncogene 27(47):6120-6130

160. Alam M, Ahmad R, Rajabi H, Kharbanda A, Kufe D (2013) MUC1-C oncoprotein activates ERK $\rightarrow \mathrm{C} / \mathrm{EBP} \beta$ signaling and induction of aldehyde dehydrogenase $1 \mathrm{~A} 1$ in breast cancer cells. J Biol Chem 288(43):30892-30903
161. Rosenthal DT, Zhang J, Bao L, Zhu L, Wu Z, Toy K, Kleer CG, Merajver SD (2012) RhoC impacts the metastatic potential and abundance of breast cancer stem cells. PLoS One 7(7):e40979

162. Raha D, Wilson TR, Peng J, Peterson D, Yue P, Evangelista M, Wilson C, Merchant M, Settleman J (2014) The cancer stem cell marker aldehyde dehydrogenase is required to maintain a drugtolerant tumor cell subpopulation. Cancer Res 74(13):3579-3590

163. Kim SK, Kim H, D-h Lee, T-s Kim, Kim T, Chung C, Koh GY, Kim H, Lim D-S (2013) Reversing the intractable nature of pancreatic cancer by selectively targeting ALDH-high, therapyresistant cancer cells. PLoS One 8(10):e78130

164. Chen D, Cui QC, Yang H, Dou QP (2006) Disulfiram, a clinically used anti-alcoholism drug and copper-binding agent, induces apoptotic cell death in breast cancer cultures and xenografts via inhibition of the proteasome activity. Cancer Res 66(21):10425-10433

165. Lövborg H, Öberg F, Rickardson L, Gullbo J, Nygren P, Larsson $\mathrm{R}$ (2006) Inhibition of proteasome activity, nuclear factor-KB translocation and cell survival by the antialcoholism drug disulfiram. Int J Cancer 118(6):1577-1580

166. Cen D, Gonzalez RI, Buckmeier JA, Kahlon RS, Tohidian NB, Meyskens FL (2002) Disulfiram induces apoptosis in human melanoma cells: a redox-related process1. Mol Cancer Ther 1(3):197-204

167. Morrison BW, Doudican NA, Patel KR, Orlow SJ (2010) Disulfiram induces copper-dependent stimulation of reactive oxygen species and activation of the extrinsic apoptotic pathway in melanoma. Melanoma Res 20(1):11-20

168. Yip N, Fombon I, Liu P, Brown S, Kannappan V, Armesilla A, Xu B, Cassidy J, Darling J, Wang W (2011) Disulfiram modulated ROSMAPK and NFאB pathways and targeted breast cancer cells with cancer stem cell-like properties. Br J Cancer 104(10):1564-1574

169. Zhang H, Chen D, Ringler J, Chen W, Cui QC, Ethier SP, Dou QP, Wu G (2010) Disulfiram treatment facilitates phosphoinositide 3-kinase inhibition in human breast cancer cells in vitro and in vivo. Cancer Res 70(10):3996-4004

170. Shian S-G, Kao Y-R, Wu FY-H, Wu C-W (2003) Inhibition of invasion and angiogenesis by zinc-chelating agent disulfiram. Mol Pharmacol 64(5):1076-1084

171. Marikovsky M, Ziv V, Nevo N, Harris-Cerruti C, Mahler O (2003) $\mathrm{Cu} / \mathrm{Zn}$ superoxide dismutase plays important role in immune response. J Immunol 170(6):2993-3001

172. Marikovsky M, Nevo N, Vadai E, Harris-Cerruti C (2002) Cu/ $\mathrm{Zn}$ superoxide dismutase plays a role in angiogenesis. Int $\mathrm{J}$ Cancer 97(1):34-41

173. Cho H, Lee T, Park J, Park K, Sin D, Park Y, Moon Y, Lee K, Yeo J (2007) Disulfiram suppresses invasive ability of osteosarcoma cells via the inhibition of MMP-2 and MMP-9 expression. J Biochem Mol Biol 40(6):1069

174. Duan X, Xiao J, Yin Q, Zhang Z, Yu H, Mao S, Li Y (2014) Multi-targeted inhibition of tumor growth and lung metastasis by redox-sensitive shell crosslinked micelles loading disulfiram. Nanotechnology 25(12):125102

175. Nechushtan H, Hamamreh Y, Nidal S, Gotfried M, Baron A, Shalev YI, Nisman B, Peretz T, Peylan-Ramu N (2015) A phase IIb trial assessing the addition of disulfiram to chemotherapy for the treatment of metastatic non-small cell lung cancer. Oncologist 20(4):366-367

176. Pors K, Loadman PM, Shnyder SD, Sutherland M, Sheldrake HM, Guino M, Kiakos K, Hartley JA, Searcey M, Patterson LH (2011) Modification of the duocarmycin pharmacophore enables CYP1A1 targeting for biological activity. Chem Commun 47(44):12062-12064

177. Sheldrake HM, Travica S, Johansson I, Loadman PM, Sutherland M, Elsalem L, Illingworth N, Cresswell AJ, Reuillon T, Shnyder SD (2013) Re-engineering of the Duocarmycin 
structural architecture enables bioprecursor development targeting CYP1A1 and CYP2W1 for biological activity. J Med Chem 56(15):6273-6277

178. Sutherland M, Gill JH, Loadman PM, Laye JP, Sheldrake HM, Illingworth NA, Alandas MN, Cooper PA, Searcey M, Pors K (2013) Antitumor activity of a duocarmycin analogue rationalized to be metabolically activated by cytochrome P450 1A1 in human transitional cell carcinoma of the bladder. Mol Cancer Ther 12(1):27-37

179. Travica S, Pors K, Loadman PM, Shnyder SD, Johansson I, Alandas MN, Sheldrake HM, Mkrtchian S, Patterson LH, Ingelman-Sundberg M (2013) Colon cancer-specific cytochrome P450 2W1 converts duocarmycin analogues into potent tumor cytotoxins. Clin Cancer Res 19(11):2952-2961

180. Neumeister V, Agarwal S, Bordeaux J, Camp RL, Rimm DL (2010) In situ identification of putative cancer stem cells by multiplexing ALDH1, CD44, and cytokeratin identifies breast cancer patients with poor prognosis. Am J Pathol 176(5):2131-2138

181. Zhong Y, Shen S, Zhou Y, Mao F, Guan J, Lin Y, Xu Y, Sun Q (2014) ALDH1 is a better clinical indicator for relapse of invasive ductal breast cancer than the CD44+/CD24- phenotype. Med Oncol 31(3):1-8

182. Opdenaker LM, Arnold KM, Pohlig RT, Padmanabhan JS, Flynn DC, Sims-Mourtada J (2014) Immunohistochemical analysis of aldehyde dehydrogenase isoforms and their association with estrogen-receptor status and disease progression in breast cancer. Breast Cancer 6:205

183. Qiu Y, Pu T, Li L, Cheng F, Lu C, Sun L, Teng X, Ye F, Bu H (2014) The expression of aldehyde dehydrogenase family in breast cancer. J Breast Cancer 17(1):54-60

184. Tan EY, Thike AA, Breast Surgical Team at O, Tan PH (2013) ALDH1 expression is enriched in breast cancers arising in young women but does not predict outcome. $\mathrm{Br} \mathrm{J}$ Cancer 109(1):109-113

185. Liu S, Liu C, Min X, Ji Y, Wang N, Liu D, Cai J, Li K (2013) Prognostic value of cancer stem cell marker aldehyde dehydrogenase in ovarian cancer: a meta-analysis. PLoS One 8(11):e81050

186. Rasper M, Schäfer A, Piontek G, Teufel J, Brockhoff G, Ringel F, Heindl S, Zimmer C, Schlegel J (2010) Aldehyde dehydrogenase 1 positive glioblastoma cells show brain tumor stem cell capacity. Neuro-oncology:noq070

187. Zhang W, Yan W, You G, Bao Z, Wang Y, Liu Y, You Y, Jiang $T$ (2013) Genome-wide DNA methylation profiling identifies ALDH1A3 promoter methylation as a prognostic predictor in G-CIMP - primary glioblastoma. Cancer Lett 328(1):120-125

188. Gangavarapu KJ, Azabdaftari G, Morrison CD, Miller A, Foster BA, Huss WJ (2013) Aldehyde dehydrogenase and ATP binding cassette transporter G2 (ABCG2) functional assays isolate different populations of prostate stem cells where ABCG2 function selects for cells with increased stem cell activity. Stem Cell Res Ther 4(5): 132

189. Wu J, Mu Q, Thiviyanathan V, Annapragada A, Vigneswaran N (2014) Cancer stem cells are enriched in Fanconi anemia head and neck squamous cell carcinomas. Int J Oncol 45(6):2365-2372

190. Deng Y, Zhou J, Fang L, Cai Y, Ke J, Xie X, Huang Y, Huang M, Wang J (2014) ALDH1 is an independent prognostic factor for patients with stages II-III rectal cancer after receiving radiochemotherapy. Br J Cancer 110(2):430-434

191. Patlolla JM, Qian L, Biddick L, Zhang Y, Desai D, Amin S, Lightfoot S, Rao CV (2013) $\beta$-Escin Inhibits NNK-induced lung adenocarcinoma and ALDH1A1 and RhoA/Rock expression in $\mathrm{A} / \mathrm{J}$ mice and growth of $\mathrm{H} 460$ human lung cancer cells. Cancer Prev Res 6(10):1140-1149

192. Giacalone NJ, Den RB, Eisenberg R, Chen H, Olson SJ, Massion PP, Carbone DP, Lu B (2013) ALDH7A1 expression is associated with recurrence in patients with surgically resected non-small-cell lung carcinoma. Future Oncol 9(5):737-745

193. Boonyaratanakornkit JB, Yue L, Strachan LR, Scalapino KJ, LeBoit PE, Lu Y, Leong SP, Smith JE, Ghadially R (2010) Selection of tumorigenic melanoma cells using ALDH. J Invest Dermatol 130(12):2799-2808

194. Z-1 Yang, Yang L, Zou Q, Yuan Y, Li J, Liang L, Zeng G, Chen S (2013) Positive ALDH1A3 and negative GPX3 expressions are biomarkers for poor prognosis of gallbladder cancer. Dis Markers 35(3):10 